\title{
Gastrointestinal Neuroendocrine Tumors
}

\author{
Ozcan Yildiz and Suheyla Serdengecti \\ Istanbul University/Cerrahpasa Medical Faculty,Department of Internal Medicine, \\ Division of Medical Oncology Istanbul, \\ Turkey
}

\section{Introduction}

Gastrointestinal carcinoid tumors date back to 1888 when Otto Lubarsch found multiple tumors in the distal ileum of two patients at autopsy (Lubarsch, 1888). The German pathologist Siegfried Oberndorfer was the first who used the term "Karzinoide Tumoren", the English translation of which is "carcinoid tumor". He coined this term because these tumors behaved less aggressively than true carcinomas (Oberndorfer, 1907). Oberndorfer contributed to the Department of Pathology of Istanbul University where he remained full professor and director until his death in 1944 (Dogan \& Hot, 2010; Klöppel et al., 2007). In 1914, Gosset and Masson first mentioned neuroendocrine features of carcinoid tumors. In 1954, Thorson and co-workers described the term "carcinoid syndrome" after they found that the tumors contained serotonin and patients with small intestinal carcinoid tumor and liver metastases presented with the characteristic symptoms of diarrhea, flushing, asthma, and right heart failure (Thorson et al., 1954). It was soon recognized as a distinct entity after they were reported in several organs belonging to bronchopulmonary system and gastrointestinal tract (Yalcin, 2006). Although better named as "neuroendocrine tumors" after the WHO meeting in 2000, these tumors have been traditionally called "carcinoids" especially at some specific locations such as the gastrointestinal tract. Therefore, the terms "carcinoid tumor" and "neuroendocrine tumor" are used interchangeably throughout the text.

\section{Epidemiology}

Although it might not reflect the true incidence due to their indolent nature, the overall incidence of carcinoid tumors in the United.States has been estimated to be 1 to 2 cases per 100,000 people (Godwin, 1975; Modlin \& Sandor, 1997). Yao and co-workers reviewed 35,825 neuroendocrine tumors (NETs) compiled from 1973 to 2004 (Yao et al., 2008). According to this review, 41\% was foregut NETs, $26 \%$ midgut NETs, and $19 \%$ hindgut NETs. In the remaining $13 \%$, the primary tumor site was unknown or could not be classified. These figures were similar to our institution's patient cohort (Yildiz et al., 2009). In Sweden, combined with the autopsy series the incidence has been calculated to be 8.4 cases per 100,000 people. Based on the data from the End Results Group (1950-1969) and the Third National Cancer Survey (1969-1971) the most common site of carcinoid tumors was appendix followed by the rectum, ileum, lung and bronchi, and stomach (Godwin, 1975). Pancreatic endocrine tumors are relatively less frequent and account for $2 \%$ of malignant 
tumors of the gastrointestinal tract. Recent data obtained from the National Cancer Institute Surveillance, Epidemiology, and End Results program (1973 to 1997) showed that, of the 11,427 cases analyzed, the overall incidence rates for carcinoid tumors have increased significantly over the past 25 years, although rates for some sites have decreased (e.g., appendix). The gastrointestinal tract accounted for $54.5 \%$ of the tumors. Within the gastrointestinal tract, the small intestine was the most common site $(44.7 \%)$, followed by the rectum $(19.6 \%)$, appendix $(16.7 \%)$, colon $(10.6 \%)$, and stomach $(7.2 \%)$. The average age was 60.9 years, and $54.2 \%$ were female. The 5-year survival rates for the most common gastrointestinal sites were $75.1 \%$ for stomach, $76.1 \%$ for small intestine, $76.3 \%$ for appendix, and $87.5 \%$ for rectum (Maggard et al., 2004).

\section{Pathology and classification}

Carcinoid tumors are thought to arise primarily from the neuroendocrine cells of the lung and the gastrointestinal tract. In the past, these cells were called "Kulchitsky cells" or "enterochromaffin cells" due to the affinity for soluble silver salts, hence the term argentaffinomas. Although not prognostically useful, historically, carcinoid tumors have been classified according to their embryologic derivation within the primitive gut (Williams \& Sandler, 1963): Foregut, midgut, and hindgut carcinoids. Foregut carcinoids include intrathoracic (thymic and bronchial), gastric, esophageal, upper duodenal, and pancreatic carcinoids. They usually produce low levels of serotonin, 5-hydroxytryptophan (5-HTP), histamine, or adrenocorticotropic hormone. Midgut carcinoids include carcinoids of distal duodenum, jejunum, ileum, appendix, proximal colon, liver, ovary, or testes. These tumors have the propensity of producing serotonin at high levels. Finally, hindgut carcinoids include carcinoids of distal colon and rectum. They less likely produce serotonin but may produce somatostatin, peptide YY, 5-HTP, or other hormones (Table 1).

Useful immunohistochemical markers in modern pathology include neuron-specific enolase (NSE), synapthophysin and chromogranin A (CgA) which is also a secretory product of the carcinoid cells used to monitor disease activity (Table 2). On gross examination, carcinoid tumors are small yellow nodules located submucosally. When they invade the serosa, an intense desmoplastic reaction occurs that may lead to intestinal kinking and obstruction.

The WHO 1980 classification had taken into account the histologic features apart from the site of origin (Bosman et al., 2010; table 3). According to this revised system, welldifferentiated neuroendocrine tumors are typical tumors that show characteristic growth pattern and benign behavior. They are indolent tumors, confined to mucosa or submucosa, and less than 1 to $2 \mathrm{~cm}$ in diameter.

In the WHO 2000 classification, features such as differentiation and proliferation were retained, but location, tumor size, tumor extent, and angioinvasion were transferred into the TNM (Tumor, Node, Metastasis) staging classification. The WHO 2010 classification states that all GEP-NETs are potentially malignant, but differ in their ability of metastasis (Rindi et al., 2010). Well-differentiated NETs are classified together as neuroendocrine tumors (NETs) G1 or G2. NET G1 is analogous with carcinoid. The term neuroendocrine carcinoma (NEC), unlike NET, refers to all poorly differentiated NETs. NEC is further subdivided into a smallcell and a large-cell variant. In respect of proliferation, all NECs are actively proliferating G3 tumors. Mixed adenoneuroendocrine carcinomas (MANEC) and hyperplastic and preneoplastic lesions are special groups. This classification is complemented by GEP-NET- 
specific TNM classifications and a grading system, which improves prognostic and treatment stratification (Schott et al., 2011).

\begin{tabular}{|l|c|}
\hline Secretory products of carcinoid tumors & Frequency (\%) \\
\hline Amines & - \\
\hline 5-Hydroxytrypta mine & 88 \\
\hline 5-Hydroxyindoleacetic acid & - \\
\hline 5-Hydroxytryptophan & - \\
\hline 5-Hydroxyindoleacetaldehyde & - \\
\hline Histamine & - \\
\hline Dopamine & - \\
\hline Tachykinins & - \\
\hline Kallikrein & 32 \\
\hline Substance P & 66 \\
\hline Neuropeptide K & \\
\hline Peptides & 43 \\
\hline Pancreatic polypeptide & 100 \\
\hline Chromogranins & 41 \\
\hline Neurotensin & 28 \\
\hline Human chorionic gonadotrophin-alpha & 12 \\
\hline Human chorionic gonadotropin-beta & 14 \\
\hline Motilin & - \\
\hline Pancreastatin & \\
\hline Other & - \\
\hline Prostaglandins & \\
\hline
\end{tabular}

(O’Dorisio, 2011; Vinik et al., 2008; Norheim et al., 1987; Feldmann \& O'Dorisio 1986; Eriksson et al., 1990)

Table 1. Secretory products and known frequency of carcinoid tumors

\begin{tabular}{|l|l|l|}
\hline Foregut & Midgut & Hindgut \\
\hline Argyrophilic & Argentaffin-positive & Argyrophilic \\
\hline CgA-positive & CgA-positive & CgA-positive \\
\hline NSE-positive & NSE-positive & NSE-positive \\
\hline Synaptophysin-positive & Synaptophysin-positive & Synaptophysin-positive \\
\hline & & SVP-2-positive \\
\hline
\end{tabular}

CgA: Chromogranin A; SVP-2: Seminal vesicle protein-2; NSE: neuron specific enolase

Table 2. Immunestaining of carcinoid tumors regarding their embryonic origin

Well-differentiated endocrine tumors may exhibit uncertain behavior. They may be angioinvasive. They may also produce serotonin and enteroglucagon. Another subset is well-differentiated endocrine carcinomas once termed "atypical" or "anaplastic". They are subdivided into low-grade and high-grade malignant carcinoids. Low-grade malignant carcinoids are deeply invasive (muscularis propria or beyond) and serotonin-producing 
when metastatic disease develops. High-grade malignant carcinoids, on the other hand, are small to intermediate carcinomas. Appendiceal and rectal carcinoids are rarely malignant, whereas ileal, type III gastric, and colonic ones are frequently malignant. Size is also a predictor of the malignant potential of the carcinoid tumor. More than $66 \%$ of carcinoids greater than $2 \mathrm{~cm}$ exhibit distant spread when first diagnosed (Capella et al., 1995).

\begin{tabular}{|c|c|c|c|c|c|}
\hline & \multirow{4}{*}{$\begin{array}{l}\text { WHO } 1980 \\
\text { Carcinoid }\end{array}$} & \multicolumn{2}{|r|}{ WHO 2000} & \multicolumn{2}{|r|}{ WHO 2010} \\
\hline I. & & 1. & $\begin{array}{l}\text { Well-differentiated } \\
\text { differentiated } \\
\text { endocrine tumor } \\
\text { (WDET) }\end{array}$ & 1. & $\begin{array}{l}\text { Neuroendocrine tumor } \\
\text { G1 (Carcinoid) }\end{array}$ \\
\hline & & 2. & $\begin{array}{l}\text { Well-differentiated } \\
\text { endocrine } \\
\text { carcinoma (WDEC) }\end{array}$ & 2. & NET G2 \\
\hline & & 3. & $\begin{array}{l}\text { Poorly } \\
\text { differentiated } \\
\text { (small-cell) } \\
\text { endocrine } \\
\text { carcinoma (PDEC) }\end{array}$ & 3. & $\begin{array}{l}\text { Small or large-cell } \\
\text { neuroendocrine } \\
\text { carcinoma G3 (NEC) }\end{array}$ \\
\hline $\begin{array}{l}\text { II. } \\
\text { III. }\end{array}$ & $\begin{array}{l}\text { Mucocarcinoid } \\
\text { Mixed carcinoid- } \\
\text { adenocarcinoma }\end{array}$ & 4. & $\begin{array}{l}\text { Mixed endocrine- } \\
\text { exocrine carcinoma } \\
\text { (MEEC) }\end{array}$ & 5. & $\begin{array}{l}\text { Mixed } \\
\text { adenoneuroendocrine } \\
\text { carcinoma }\end{array}$ \\
\hline IV. & $\begin{array}{l}\text { Pseudotumorous } \\
\text { lesion }\end{array}$ & 6. & $\begin{array}{l}\text { Tumor-like lesions } \\
\text { (TLL) }\end{array}$ & 7. & $\begin{array}{l}\text { Hyperplastic and } \\
\text { preneoplastic lesion }\end{array}$ \\
\hline
\end{tabular}

Table 3. Comparison of the WHO classifications of gastroenteropancreatic neuroendocrine tumors. Bosman FT, et al., WHO classification of tumors of the digestive system. Lyon, France: IARC Press; 2010.

\section{Clinical chemistry}

Clinically functioning carcinoid tumors produce typical syndromes according to the specific circulating peptide. One of the best-characterized of these peptides is serotonin (5-HT). It is synthesized from 5-hydroxytryptophan (5-HTP) and metabolized to 5-hydroxyindoleacetic acid (5-HIAA) which is excreted in the urine. Measurement of 5-HIAA in the urine is an important tumor marker in the carcinoid syndrome, especially in midgut carcinoids. Recently, measurements of serotonin in platelets have been recommended for the detection of carcinoid tumors that secrete only small amounts of serotonin and/or its precursor 5hydroxytryptophan (Kema et al., 2000). Tumors originating from foregut carcinoids (lung, pancreas, and stomach) may have relatively low levels of 5-HTP decarboxylase. 5-HTP, 5$\mathrm{HT}$, and 5-HIAA are excreted in the urine.

\section{Clinical features of individual carcinoids}

\subsection{Foregut carcinoids}

For the sake of completeness we will discuss thymic and pulmonary carcinoids in the following sections. 


\subsubsection{Thymic carcinoids}

Thymic carcinoids are rare and may be part of multiple endocrine neoplasia type 1 (MEN1). The tumor is usually non-functioning and occurs as an anterior mediastinal mass. The mass may be partly calcified and may cause superior vena cava obstruction. Extension into the pleura, pericardium, great vessels, or regional lymph nodes is commonly seen. Functioning thymic carcinoids usually secrete adrenocorticotrophic hormone (ACTH), which may lead to Cushing's syndrome. In these cases bilateral adrenal hyperplasia may also be seen. Other hormones include corticotrophin-releasing hormone, growth hormone-releasing hormone (GHRH) and 5-HT. Carcinoid syndrome has been described with a multidirectional carcinoma of the thymus with neuroendocrine and sarcomatous components. (Paties et al., 1991)

\subsubsection{Pulmonary carcinoids}

Pulmonary carcinoid tumors comprise about $2 \%$ of primary lung tumors. They are believed to arise from neuroendocrine Kulchitsky's cells of the proximal bronchial mucosa, and bronchopulmonary tract is the second common site of carcinoid tumors after the gastrointestinal system. They have been classified into three groups, according to their malignant potential: Benign or classical bronchial carcinoid, low-grade malignant or atypical carcinoid, and high-grade malignant or poorly differentiated carcinoma of the large cell or small cell type.

Neuroendocrine tumors of the lung can also be divided into 5 groups: Tumorlet, diffuse idiopathic pulmonary neuroendocrine cell hyperplasia (DIPNECH) (Nassar et al., 2011), carcinoid tumor, atypical carcinoid tumor, and small cell carcinoma of the lung. Typical carcinoids of the lung present in the fifth decade of life and are more common in females. These tumors are not related to smoking. Neuroendocrine manifestations are relatively uncommon. Common symptoms are cough, hemoptysis, wheezing, and chest pain (Table 4). Recurrent pneumonia can occur due to obstructing lesions. Cushing's syndrome and acromegaly may be seen due to the secretion of ACTH and GHRH, respectively. The prognosis is excellent for classical bronchial carcinoids. Diagnostic tools for pulmonary carcinoids are generally non-specific. Bronchoscopic biopsy should be used to obtain diagnostic tissue, despite the feared complication of hemorrhage.

\begin{tabular}{|l|l|}
\hline Carcinoid tumors & Clinical features \\
\hline $\begin{array}{l}\text { Foregut } \\
\text { Bronchial carcinoids } \\
\text { Gastric carcinoids }\end{array}$ & $\begin{array}{l}\text { Cough, hemoptysis, wheezing, chest pain, pneumonia } \\
\text { Usually found incidentally }\end{array}$ \\
\hline $\begin{array}{l}\text { Midgut } \\
\text { Small intestinal carcinoids } \\
\text { Appendiceal carcinoids }\end{array}$ & $\begin{array}{l}\text { Bowel obstruction } \\
\text { Nonspecific abdominal pain, carcinoid syndrome } \\
\text { Usually found incidentally }\end{array}$ \\
\hline Hindgut & Bleeding, pain, constipation, carcinoid syndrome \\
Rectal carcinoids &
\end{tabular}

Table 4. Clinical features of neuroendocrine tumors 
Treatment should not be radical unless there is lymph node metastasis. Options include lobectomy, segmentectomy, and bronchotomy with tumor enucleation. Curative or palliative metastasectomies are worth trying since they grow slowly. Carcinoid crisis should be prevented with octreotide administration preoperatively. When chemotherapy is indicated in some patients, 5-fluorouracil and streptozotosin or cisplatin and etoposide are most commonly used regimens. Other drugs used in metastatic pulmonary carcinoids are octreotide, 131I-MIBG, and interferon alpha. Stage-by-stage, the outcome is worse for patients with atypical carcinoids than for those with typical carcinoids (Kaplan et al., 2003).

\subsubsection{Gastric carcinoids}

Gastric carcinoids are rare neoplasms of the stomach comprising less than $1 \%$ of gastric tumors and 8.7\% of all gastrointestinal neuroendocrine tumors (Godwin, 1975; Modlin et al., 1997) (Table 4). The incidence is reported to be 1.2 and $1.8 / 1,000,000$ persons/year in white males and females, respectively. Three types have been described: Those associated with chronic atrophic gastritis type A (CAG-A or type I), those associated with Zollinger-Ellison syndrome (type II), and sporadic gastric carcinoid tumors (type III). The first 2 groups of carcinoids are associated with hypergastrinemia. CAG-A associated carcinoids are the most common type $(70-80 \%$ of cases). The typical patient is a woman in her sixties with pernicious anemia, hypochlorhydria, and hypergastrinemia. High levels of gastrin may mediate the hyperplasia of enterochromaffin-like (ECL) cells in the gastric mucosa and ultimately, carcinoid tumors may develop. They are small indolent, non-functioning tumors and located multifocally in the body or fundus, which are diagnosed incidentally (Rindi et al., 1993; Gough et al., 1994; Moses et al., 1986). Tumors less than $1 \mathrm{~cm}$ have been successfully resected and followed endoscopically (Ahlman et al., 1994; Sjoblom et al., 1993). Gastric carcinoids associated with the Zollinger-Ellison syndrome (ZES) almost always occur in patients with multiple endocrine neoplasia type 1 (MEN1 or Wermer's syndrome) suggesting a genetic predisposition. Five percent of gastric carcinoids are of type II. The treatment and prognosis are similar to those of CAG-A associated carcinoids. Within this group, there is also a non-MEN1 associated sporadic ZES which rarely leads to gastric carcinoid tumor development. Interestingly, 99\% of them had ECL hyperplasia and abnormal alpha-human chorionic gonadotropin (a-hCG) staining. Sporadic gastric carcinoids (type III), in contrast, are not associated with hypergastrinemia and follow an aggressive clinical course. In addition to being solitary, they are usually more than $1 \mathrm{~cm}$ in size and often metastatic at the time of diagnosis. When feasible, radical gastrectomy is the treatment of choice.

\subsection{Midgut carcinoids}

\subsubsection{Small intestinal carcinoids}

Small bowel is not only the most frequent site of carcinoid tumors (including metastatic carcinoids), but also carcinoids are the commonest primary malignant tumor of the distal small intestine. Their frequency has recently surpassed adenocarcinoma (44\% versus 33\%) (Bilimoria et al., 2009). More than one third of the small bowel tumors are diagnosed as carcinoids and of all gastrointestinal carcinoids; $42 \%$ arise in the small bowel of which the ileum represents the most common localization followed by the duodenum and the jejunum. The annual incidence rate is 0,28 per 100,000 . Patients usually present in 6 th or 7 th 
decade of life with mechanical obstruction or vague abdominal pain, sometimes for several years before the diagnosis perhaps due to their submucosal location. These tumors are thought to originate from serotonin-producing intraepithelial endocrine cells and they tend to have high serotonin content. They are multicentric and the most frequent location is the distal ileum. Lymph node and liver metastasis are common but carcinoid syndrome is seen only in 5 to $7 \%$ of the patients (Burke et al., 1997; Bilimoria et al., 2009). Metastases tend to occur in liver, bone and lung. Unlike appendiceal carcinoids, smaller tumors have also been found to have metastasized. Nevertheless, tumors measuring $2 \mathrm{~cm}$ in diameter have almost always been proved to have distant spreading.

Based on patients, registered in the Swedish Cancer Registry, with small intestinal carcinoids diagnosed from 1960 to 2000 in the duodenum $(n=89)$ and jejunum/ileum $(n=2437)$, the overall 5-, 10-, and 15 year survivals were, respectively, 60, 46, and $28 \%$ for duodenal tumors and 56, 36, and 23\% for jejunal/ileal tumors (Zar et al., 2004).

\subsubsection{Appendiceal carcinoids}

Carcinoid tumors are the most common cancers of the appendix (Moertel et al., 1968) originating from subepithelial endocrine cells (Lundqvist \& Wilander, 1986; Shaw, 1990). They are detected most commonly after appendectomy performed for other reasons and they are found in 0.3-0.9\% of patients undergoing appendectomy (Goede et al., 2003). Median age is 4 th or 5 th decade of life (Modlin \& Sandor, 1997). This age range is partly explained by higher appendectomy rate in young adults. Less than $10 \%$ of appendiceal carcinoids cause symptoms due to the distal localization of the tumor (Moertel et al., 1987). However, they become symptomatic earlier than the carcinoids of other sites. This may also explain the relatively less frequent metastasis of appendiceal carcinoids regarding tumor size. On the other hand, the size of the tumor is the best predictor of outcome according to the Mayo Clinic series. The critical size has been found to be $2 \mathrm{~cm}$. Therefore, right hemicolectomy is the treatment of choice for those tumors that are more than $2 \mathrm{~cm}$ in size as well as those located at the base of the appendix regardless of their size. Local desmoplasia is another indication of right hemicolectomy. Otherwise simple appendectomy suffices as there is no evidence of recurrence after a median follow-up of more than 25 years in the appropriate age group (Moertel et al., 1987).

\subsection{Hindgut carcinoids}

\subsubsection{Colonic carcinoids}

Less than 1\% of colon cancers are carcinoids (Modlin IM, 1997). The usual presentation of colonic carcinoids in patients is bleeding, pain and obstruction (Table 3). In a study of 72 patients, the more common symptoms were pain, anorexia and weight loss (Rosenberg JM, 1985). Patients were usually at their 7 th decade of life. The most common location was cecum. Midgut colonic carcinoids, namely proximal colonic ones, are believed to arise from serotonin-secreting epithelial endocrine cells, behave more aggressively and symptomatic tumors need to be approached radically. Fulguration should be avoided in colonic carcinoids due to a risk of perforation. As for prognosis, 5 -year survival rate is $70 \%$ in patients with local disease; $44 \%$ and $20 \%$ in patients with regional metastases and distant spread, respectively. 


\subsubsection{Rectal carcinoids}

Rectal carcinoids constitute 1 to $2 \%$ of all rectal cancers and are the most common hindgut carcinoid. They occur most commonly in the 6th decade of life (Modlin \& Sandor, 1997). Recent series have shown that they are relatively common (Matsui et al., 1993; Jemore et al., 1992). In one series between 1992 and 1999, they accounted for 27\% of all gastrointestinal carcinoid tumors (Modlin et al., 2003). Unlike other carcinoids, they do not usually produce serotonin and therefore do not cause carcinoid syndrome despite extensive metastases. Symptomatic patients have rectal bleeding, pain, and constipation (Table 4) (Harpole et al., 1992; Smith, 1969). They are submucosally located and almost always diagnosed with endoscopic biopsies. Size is the major factor for metastasis. Tumors less than $1 \mathrm{~cm}$ in diameter has never been shown to have metastasized during a follow up of up to 25 years according to the Mayo Clinic experience. However, tumors more than $2 \mathrm{~cm}$, which make up about $5 \%$, behave aggressively. For patients with tumors between $1 \mathrm{~cm}$ and $2 \mathrm{~cm}$, an individualized approach is appropriate considering age and comorbid conditions.

\section{Carcinoid syndrome}

The clinical presentation of the carcinoid tumors varies depending on localization, hormone production, and extent of disease. Midgut carcinoids often present with bowel obstruction or abdominal pain. Patients with rectal carcinoids often seek medical attention with bleeding. Lung carcinoids are found incidentally or they may secrete ACTH or CRH to present with Cushing's syndrome. Growth hormone-releasing hormone secreted by foregut carcinoids may cause acromegaly. Duodenal carcinoids may cause somatostatinoma syndrome. However, the most characteristic clinical feature of carcinoid tumors is carcinoid syndrome.

Carcinoid syndrome, which is almost always seen when the tumor has metastasized to the liver, is the third most common mode of presentation of carcinoid tumors after bowel obstruction and abdominal pain. A small proportion of midgut carcinoids without liver metastasis can still present with carcinoid syndrome suggesting direct liberation of the causative agents into the systemic circulation. Flushing and diarrhea are the most common components of carcinoid syndrome, which are seen up to $89 \%$ of the patients during their course of the disease. Flushing is characterized by a sudden onset, deep red or violaceous erythema of the upper body often associated with a feeling of warmth. It is the prominent symptom in midgut carcinoids, which is thought to be due to catecholamine induced kallikrein release. In bronchial carcinoids, the flushing is usually prolonged sometimes hours or days giving rise to permanent dilatation of facial veins and telangiectasia. Gastric carcinoids may cause a characteristic flush that is reddish in color and pachy in distribution reminiscent of an urticarial reaction, which may be inhibited by histamine antagonists (Adamson et al., 1969). Other manifestations include asthma, edema, right heart vulvular lesions, the most common of which is tricuspid regurgitation, a loud sound of the pulmonic component of the $2^{\text {nd }}$ heart sound, pellegra-like skin lesions, peptic ulcer, and arthralgia. Malignant carcinoid syndrome denotes patients with these manifestations combined with liver metastasis and elevated urinary 5-HIAA levels. Some patients may display only a few of the above signs. Usually, a full-blown carcinoid syndrome is seen in patients with extensive hepatic metastases. Some patients may have hepatic metastases with minimal symptoms and they generally look well. Ovarian and bronchial carcinoids may cause 
carcinoid syndrome without documented liver metastasis. While patients with small intestinal and proximal colonic carcinoids produce carcinoid syndrome most commonly, it is less commonly seen in bronchial carcinoids and does not occur in rectal carcinoids (Harpole et al., 1992; Smith, 1969; Caldarola et al., 1964). Due to the vagueness of the symptoms or no symptoms at all, diagnosis is delayed approximately 2 to 3 years (Norheim et al., 1987).

\section{Diagnosis}

The diagnosis of a carcinoid tumor depends on the symptomatology of carcinoid syndrome or the presence of other symptoms such as abdominal discomfort. Nevertheless, $60 \%$ of the patients with gastrointestinal carcinoids found at surgery were asymptomatic in one study (Thompson et al., 1985). The histopathologic diagnosis is made using immunohistochemical techniques, namely antibodies directed against chromogranin A (CgA), synaptophysin, and NSE. In patients with carcinoid syndrome the diagnosis can be made measuring urinary 5HIAA levels. Levels of 15 to $60 \mathrm{mg} / 24$ hours are compatible with midgut carcinoid tumors with 60 to $73 \%$ of sensitivity and 100\% specificity. The most sensitive marker is plasma CgA, albeit not specific, since other neuroendocrine tumors can secrete this substance. Foregut carcinoids, on the other hand, may produce an atypical carcinoid syndrome with minimally elevated or normal urinary 5-HIAA level since they lack the enzyme L-amino-acid decarboxylase. The diagnosis of these tumors rely upon measurement of urinary metabolites of tryptophan such as 5-HTP or 5-HT. Patients should abstain from bananas, avocado, pineapple, walnuts, chocolate, and coffee; and avoid drugs such as chlorpromazine (Bertino \& Cole, 1956) salicylates, and L-dopa at least 24 hours before the sample is presented to the lab (DeVita et al., 2011).

\section{Localization}

After the diagnosis has been made localization should be determined for the optimal management of the carcinoid tumor. Bronchial carcinoids are located in the airways of the central or middle third of the lung in $80 \%$ of cases. Chest $x$-ray, computed tomography (CT) or bronchoscopy is used to detect these tumors (Nessi et al., 1991). In plain radiography, they appear as a well-demarcated round or ovoid mass, often notched. Small tumors, which are often the case, are best detected by CT scanning. The mass may be visible within the bronchial lumina with an extraluminal component. In peripheral lesions, the mass is typically round or ovoid with a smooth or lobulated border. MRI is reserved for cases in which pulmonary carcinoid is suspected but cannot be visualized on CT.

As midgut carcinoids are small tumors, they are sometimes detected by angiography or somatostatin-receptor scintigraphy (SRS) if not detected by barium enema, CT or MRI. Secondary features such as liver metastases and bowel obstruction are more often visualized than the primary tumor. Liver metastasis can be visualized by CT or MRI. Positron emission tomography (PET) using 11C-5-HTP is another localization modality with a high sensitivity (Orlefors et al., 1998; Sundin et al., 2004). Echocardiography should be performed in all patients with carcinoid syndrome to detect signs of carcinoid heart disease which is associated with poor survival. 
Hindgut carcinoids are usually localized at endoscopy. They appear as solitary yellowish submucosal lesions. Endoscopic ultrasound may demonstrate invasion of the full rectal wall (stage T3) or adjacent structures (T4).

In recent years, SRS or octreoscan and iodinated meta-iodobenzylguanidine (123I-MIBG) have been introduced to localize and stage the tumor. Five somatostatin receptors are currently recognized bound to varying degrees by the analogues 111In-octreotide, 111Inlanreotide, and P829, a new technetium-99m (99mTc) analogue (Menda \& Khan, 2002). Octreotide receptor imaging is most useful for the prediction of the success of octreotide therapy. If the scan is positive, then therapy will most likely be beneficial. It is also used peroperatively for perioperative tumor detection. Imaging with 123I-MIBG can also be performed for the prediction of therapy success with 131I-MIBG. The frequency of positive imaging in carcinoid tumors is $50-75 \%$ for 123 I-MIBG and $67-96 \%$ for 1111 -octreotide. 123 IMIBG scintigraphy, which is more widely available, appears to be more sensitive for sympatho-adrenomedullary tumors such as pheochromocytomas and paragangliomas, whereas 111ln-octreotide detects more tumors in all other neuroendocrine neoplasms.

\section{Management of carcinoid tumors}

Tumor reduction and symptomatic control are the mainstays of treatment of carcinoid tumors. When the tumor is localized, surgical resection the extent of which is determined primarily by the tumor size, is the treatment of choice. Symptomatic control includes lifestyle changes, dietary supplementation, and medical treatments directed to specific symptoms of carcinoid syndrome. Benign cases can respond to avoiding physical and emotional stress, alcohol, spicy food, and certain drugs. Supplemental niacin is recommended in patients whose symptoms are due to serotonin excess to prevent pellegra. Heart failure due to carcinoid heart disease requires drugs such as angiotensin-converting enzyme (ACE) inhibitors and diuretics. Diarrhea may respond to loperamide or diphenoxylate. Side effects of these drugs are the main limiting factor in controlling carcinoid syndrome. Therefore, more specific drugs have been developed, one of which is octreotide, a somatostatin analogue.

\subsection{Surgical palliation}

Patients suspected with intestinal obstruction must be relieved of their obstruction even if they have extensive liver metastases. Liver metastases can be resected without jeopardizing survival in select patients (Que et al., 1995; McEntee et al., 1990; \& Dousset, 1996). Liver resection has been associated with improved 5 year survival rates in several series and is recommended in appropriate patients to attempt cure or to debulk metastatic disease (Sutton et al., 2003). Embolization of the hepatic artery is another option for liver disease. Liver transplantation for highly selected patients offers a five-year survival rate of $69 \%$ according to a French study (Le Treut et al., 1997). Mesenteric ischemia should promptly be recognized and the affected bowel segment resected.

\subsection{Somatostatin analogues}

Somatostatin analogues interact with cellular and transmembrane somatostatin receptors coupled with $G$ proteins. Five subtypes have been defined. Subtypes 2, 3 and 5 are most 
important and somatostatin analogues exert their action primarily by binding to subtype 2 (Kubota et al., 1994). Activation results in inhibition of growth factor production and release as well as antiproliferative effects (Scarpignato \& Pelosini, 2001; Buscail et al., 1995; Cordelier et al., 1997 \& Cattaneo et al., 1996). Receptor subtype 3 mediates phosphotyrosine phosphatase dependent apoptosis during high dose therapy (3mg daily octreotide or $12 \mathrm{mg}$ daily lanreotide) (Imam et al., 1997). Octreotide is the most widely available drug followed by lanreotide and vapreotide. Subcutaneous administration of these drugs can control the symptoms in most of the patients. The recommended dose of immediate release form of octreotide is $100 \mathrm{mcg} 2$ or 3 times a day. The dose should be titrated upwards according to the symptoms sometimes up to $3000 \mathrm{mcg}$ a day in 3 to 7 days. Tolerance is a common caveat in long-term use. Long-acting, slow-release formulation of octreotide with 20 and $30 \mathrm{mg}$ of doses (up to $60 \mathrm{mg}$ ) every month (every 2 weeks for lanreotide) has enabled patients to enjoy a more comfortable life in terms of controlling symptoms and reducing the number of injections. The immediate release formulation and the long-acting form should overlap at least 2 weeks to achieve maximal symptom control. Patients with breakthrough symptoms may benefit from subcutaneous administration of the immediate release formulation. Treatment should be continued life-long or until troublesome side effects develop. Somatostatin analogues improve symptoms in $88 \%$ of patients and in $72 \%$, urinary 5 -HIAA excretion decreases (Kvols et al., 1986).

\subsection{Chemotherapy}

Metastatic carcinoid tumors are indolent tumors and response to chemotherapeutics is generally poor. Classical midgut carcinoids do not show any response to chemotherapy. Since foregut carcinoids are more malignant than others, cytotoxic therapy can be attempted. Combinations include streptozotocin plus 5-fluorouracil, doxorubicin, cisplatin plus etoposide, and dacarbazine plus 5-fluorouracil (Moertel et al., 1991; Di Bartolomeo et al., 1995 \& Bajetta et al., 1998). Somatostatin analogues can be combined with the above regimens. A recent study showed that chemotherapy naïve patients with metastatic pancreatic endocrine carcinomas had an exceptionally high and durable response rate with the combination of temezolamide and capecitabine (Strosberg et al., 2011).

\subsection{Immunotherapy}

Oberg and his coworkers have reported a study form Sweden that $42 \%$ of patients with carcinoid syndrome had a reduction of their urinary 5-HIAA levels when treated with low dose human leukocyte interferon and recombinant leukocyte interferon-a (Oberg et al., 1986), but there was only $11 \%$ tumor regression rate. Mayo Clinic tried higher doses of interferon (Moertel et al., 1991) and objective tumor regression was $20 \%$ but it was not durable. Toxicity was the major drawback. Oberg has suggested the dose of interferon be titrated according to the patient's neutrophil count.

\subsection{Angiogenesis inhibitors}

As neuroendocrine tumors are highly vascular tumors bevacizumab, a monoclonal antibody targeting vascular endothelial growth factor (VEGF), was tested in advanced neuroendocrine tumors. This phase II study resulted in objective responses, reduction of 
tumor blood flow, and longer PFS in patients with carcinoid than PEG interferon treatment (Yao, 2008). Sunitinib, another molecule inhibiting VEGF receptors, is approved by FDA for the treatment of advanced or unresectable progressive well-differentiated pancreatic neuroendocrine tumors based on the phase III study stating that it improves progressionfree survival, overall survival, and the objective response rate of these tumors as compared with placebo (Raymond et al., 2011).

\subsection{Mammalian target of rapamycin (mTOR) inhibitors}

Everolimus inhibits mTOR, an intracellular serine/threonine kinase that regulates multiple signaling pahways. It showed activity in advanced or unresectable low-grade or intermediate-grade pancreatic neuroendocrine tumors (Yao et al., 2011) and approved by FDA for the treatment of advanced, unresctable, or locally advanced pancreatic neuroendocrine tumors.

\subsection{Radiation therapy}

External irradiation has been used for the palliation of bone and brain metastases (Schupak \& Wallner, 1991 \& Kimmig, 1994). Radiolabeled MIBG has been the most widely studied agent. It showed a 30\% response rate with 125I-MIBG or 131I-MIBG (Hoefnagel et al., 1987 \& Taal et al., 1996). In one study, investigators performed a retrospective review of 98 patients with metastatic carcinoid who were treated at their institution with 131I-MIBG over a 15-year period. The median survival after treatment was 2.3 years. Patients who experienced a symptomatic response had improved survival. For the 56 patients who had 5HIAA levels monitored, the mean urine 5-HIAA levels decreased significantly after 131IMIBG treatment. Authors concluded that 131I-MIBG treatment could be recommended in select patients with metastatic carcinoid who progress despite optimal medical management. Improved survival was predicted best by symptomatic response to 131I-MIBG treatment, but not by hormone or radiographic response (Safford et al., 2004). 1111noctreotide is a somatostatin analogue-based tumor-targeted radioactive agent. It is most often used when imaging with 123I-MIBG fails to detect any tumor. When 111In-octreotide is avidly concentrated within the tumors, then radionuclide labeled octreotide can be administered. Studies with 90Y-labeled octreotide have shown that $83 \%$ of patients with carcinoid syndrome had a significant reduction in symptoms (Waldherr et al., 2001).

\subsection{Carcinoid heart disease}

In the pre-somatostatin era carcinoid heart disease used to occur in two thirds of patients with the carcinoid syndrome (Lundin et al., 1988). However, in the post-somatostatin era its incidence has dropped dramatically to 5\% (Anthony et al., 2011). Right heart is affected most commonly. Tricuspid regurgitation, tricuspid stenosis, pulmonary regurgitation, and pulmonary stenosis may all occur. It is thought that these lesions are due to the secreted factors by the carcinoid cells of the liver metastases into the hepatic vein. Serotonin is blamed to be responsible for the cardiac lesions in carcinoid syndrome. However, its role in the development of cardiac lesions is poorly understood. Left heart is less often affected due to inactivation of serotonin by lung metabolism. Valvular replacement in patients with symptomatic heart disease proved unsuccessful due to the high perioperative mortality (Robiolio et al., 1995 \& Connolly et al., 1995). 


\section{Prognosis}

Carcinoid syndrome represents an advanced disease and prognosis depends upon the site and extent of the disease. While in patients with localized disease the 5-year survival rate is approximately $65 \%$, patients with advanced disease this figure drops to $36 \%$ (Godwin et al., 1975). Female gender and young age at diagnosis are associated with a better prognosis. Presence of metastases, high CgA level, and high proliferation index (Ki-67) are indicators of a poor outcome. Once, carcinoid heart disease was a troublesome complication and a cause of early death. With modern diagnostic and therapeutic technics this is rarely seen today. Development of a secondary malignancy, namely an adenocarcinoma of the large intestine, is another cause of reduced survival in these patients (Godwin et al., 1975). Whether combined adenocarcinoma and carcinoid tumors are a composite tumor or collision tumors has been debated (Yamashina \& Flinner, 1985).

\section{Conclusion}

Neuroendocrine tumors continue to evolve with regard to diagnosis, classification epidemiology and treatment possibilities. They also provide a challenging source of testing novel drugs as their molecular targets have now started to be recognized.

\section{References}

Adamson AK, Grahame-Smith DG, Peart WS, \& Starr M. (1969). Pharmacological blockade of carcinoid flushing provoked by catecholamines and alcohol. Lancet 1969;2:293.

Ahlman H, Kolby L, \& Lundell L, et al., (1994). Clinical management of gastric carcinoid tumors. Digestion 1994;55(Suppl 3):77-85.

Anthony L, Vinik, AI. Pancreas. (2011). Evaluating the Characteristics and the Management of Patients With Neuroendocrine Tumors Receiving Octreotide LAR During a 6Year Period. Pancreas. 40(7):987-994, October 2011. doi: 10.1097/MPA.0b013e31821f66b4)

Bajetta E, Rimassa L, \& Carnaghi C, et al., (1998). 5-Fluorouracil, dacarbazine, and epirubicin in the treatment of patients with neuroendocrine tumors. Cancer 1998;83:372-378.

Bilimoria KY, Bentrem DJ, Wayne JD, Ko CY, Bennett CL, \& Talamonti MS. (2009). Small bowel cancer in the United States: changes in epidemiology, treatment, and survival over the last 20 years. Ann Surg. 2009 Jan;249(1):63-71

Bosman FT, Carneiro F, Hruban RH, Theise ND (2010). WHO classification of tumors of the digestive system. Lyon, France: IARC Press; 2010.

Burke AP, Thomas RM, Elsayed AM, \& Sobin LH. (1997). Carcinoids of the jejunum and ileum: an immunohistochemical and clinicopathologic study of 167 cases. Cancer 1997;79:1086-1093.

Buscail L, Esteve JP, \& Saint-Laurent, et al., (1995). Inhibition of cell proliferation by the somatostatin analogue RC-160 is mediated by somatostatin receptor subtypes SSTR2 and SSTR5 through different mechanisms. N Proc Natl Acad Sci USA 1995;92:1580-1584.

Caldarola Vt, Jackman Rj, Moertel Cg, \& Dockerty Mb. (1964). Carcinoid tumors of the rectum. Am J Surg. 1964;107:844-849. 
Capella C, Heitz PU, Hofler H, Solcia E, \& Kloppel G. (1995). Revised classification of neuroendocrine tumours of the lung, pancreas and gut. Virchows Arch 1995;425:547560

Cattaneo MG, Amoroso D, \& Gussoni G, et al., (1996). A somatostatin analogue inhibits MAP kinase activation and cell proliferation in human neuroblastoma and in human small cell lung carcinoma cell lines. FEBS Lett 1996;397:164-168.

Cordelier P, Esteve JP, \& Bousquet C, et al., (1997). Characterization of the antiproliferative signal mediated by the somatostatin receptor subtype sst5. Proc Natl Acad Sci USA 1997;94:9343-9348.

Connolly HM, Nishimura RA, Smith HC, Pellikka PA, Mullany CJ, \& Kvols LK. (1995). Outcome of cardiac surgery for carcinoid heart disease. J Am Coll Cardiol 1995;25:410-416.

Di Bartolomeo M, Bajetta E, \& Bochicchio AM, et al., (1995). A phase II trial of dacarbazine, fluorouracil and epirubicin in patients with neuroendocrine tumours. A study by the Italian Trials in Medical Oncology (I.T.M.O.) Group. Ann Oncol 1995;6:77-79.

Dogan H. \& Hot I. (2010). Contributions of Siegfried Oberndorfer to pathology and evolution of carcinoid. Pol J Pathol. 2010;61(1):49-53.

Doherty, GM. (2011). Neuroendocrine (carcinoid) tumors and the carcinoid syndrome, In: Cancer Principles \& Practice of Oncology, DeVita, Jr. VT, Lawrence T, Rosenberg SA, pp. (1503-1515), Wolters Kluwer, Lippincott Williams \& Wilkins, ISBN 978-1-45111813-1, Philadelphia

Dousset B, Saint-Marc O, Pitre J, Soubrane O, Houssin D, \& Chapuis Y. (1996). Metastatic neuroendocrine tumors: medical treatment, surgical resection, or liver transplantation. World J Surg 1996;20:908-915.

Eriksson B, Arnberg H, Oberg K, Hellman U, Lundqvist G, Wernstedt C, Wilander E. (1990). Acta Endocrinol (Copenh). A polyclonal antiserum against chromogranin A and B--a new sensitive marker for neuroendocrine tumours. 1990;;122: 145-55.

Feldman JM \& O'Dorisio TM (1986). Role of neuropeptides and serotonin in the diagnosis of carcinoid tumors. Am J Med. 1986: 81 (6B): 41-8.

Godwin JD 2nd. (1975). Carcinoid tumors. An analysis of 2,837 cases. Cancer 1975;36:560-569.

Goede AC, Caplin ME, \& Winslet MC. (2003). Carcinoid tumour of the appendix. Br J Surg 2003; 90:1317-1322.

Gough DB, Thompson GB, \& Crotty TB, et al., (1994). Diverse clinical and pathologic features of gastric carcinoid and the relevance of hypergastrinemia. World J Surg 1994;18:473-479.

Harpole DH Jr, Feldman JM, Buchanan S, Young WG, \& Wolfe WG. (1992). Bronchial carcinoid tumors: a retrospective analysis of 126 patients. Ann Thorac Surg 1992;54:50-54.

Hoefnagel CA, den Hartog Jager FC, \& Taal BG, et al., (1987). The role of 1-131-MIBG in the diagnosis and therapy of carcinoids. Eur J Nucl Med 1987;13:187-191.

Imam H, Eriksson B, \& Lukinius A, et al., (1997). Induction of apoptosis in neuroendocrine tumors of the digestive system during treatment with somatostatin analogs. Acta Oncol. 1997;36:607-614.

Jemore AB, Ray JE, \& Gathright JB et al., (1992). Rectal carcinoids: the most frequent carcinoid tumour. Dis Colon Rectum 1992;35:717-725. 
Kema IP, de Vries EG, \& Muskiet FA. (2000). Clinical chemistry of serotonin and metabolites. J Chromatogr B Biomed Sci Appl 2000;747:33-48.

Kaplan B, Stevens CW, Allen P, Liao Z, \& Komaki R. (2003). Outcomes and patterns of failure in bronchial carcinoid tumors. Int J Radiat Oncol Biol Phys 2003;55:125-131.

Kimmig BN. (1994). Radiotherapy for gastroenteropancreatic neuroendocrine tumors. Ann N Y Acad Sci 1994;733:488-495.

Klöppel G, Dege K, Remmele W, Kapran Y, Tuzlali S, Modlin IM. (2007). Siegfried Oberndorfer: a tribute to his work and life between Munich, Kiel, Geneva, and Istanbul. Virchows Arch. 2007 Aug;451 Suppl 1:S3-7. Epub 2007 Aug 8. Review

Kubota A, Yamada Y, \& Kagimoto S, et al., (1994). Identification of somatostatin receptor subtypes and an implication for the efficacy of somatostatin analogue SMS 201-995 in treatment of human endocrine tumors. J Clin Invest 1994;93:1321-1325.

Kvols LK, Moertel CG, O'Connell MJ, Schutt AJ, Rubin J, \& Hahn RG. (1986). Treatment of the malignant carcinoid syndrome: evaluation of a long-acting somatostatin analogue. N Engl J Med 1986;315:663-666.

Le Treut YP, Delpero JR, \& Dousset B, et al., (1997). Results of liver transplantation in the treatment of metastatic neuroendocrine tumors: a 31-case French multicentric report. Ann Surg 1997;225:355-364.

Lubarsch O. (1888). Ueber den primaren Krebs des Ileum, nebst Bemerkungen u'ber das gleichzeitige Vorkommen von Krebs und Tuberkolose. Virchows Arch 1888;111:280317.

Lundin L, Norheim I, Landelius J, Oberg K, Theodorsson-Norheim E. (1988). Carcinoid heart disease: relationship of circulating vasoactive substances to ultrasounddetectable cardiac abnormalities. Circulation. 1988 Feb;77(2):264-9.

Lundqvist M, \& Wilander E. (1986). Subepithelial neuroendocrine cells and carcinoid tumours of the human small intestine and appendix: a comparative immunohistochemical study with regard to serotonin, neuron-specific enolase and S-100 protein reactivity. J Pathol 1986; 148:141-147

Maggard MA, O'Connell JB, \& Ko CY. (2004). Updated population-based review of carcinoid tumors. Ann Surg, 2004;240:117-122.

Matsui K, Iwase T, \& Kitagawa M. (1993). Small, polypoid-appearing carcinoid tumors of the rectum: clinicopathologic study of 16 cases and effectiveness of endoscopic treatment. Am J Gastroenterol 1993;88:1949-1953.

McEntee GP, Nagorney DM, Kvols LK, Moertel CG, \& Grant CS. (1990). Cytoreductive hepatic surgery for neuroendocrine tumors. Surgery 1990;108:1091-1096.

Menda Y, \& Kahn D. (2002). Somatostatin receptor imaging of non-small cell lung cancer with 99mTc depreotide. Semin Nucl Med 2002;32:92-96.

Modlin IM, \& Sandor A. (1997). An analysis of 8305 cases of carcinoid tumors. Cancer, 1997;79:813-829.

Modlin IM, Lye KD, \& Kidd M. (2003). A 5-decade analysis of 13,715 carcinoid tumors. Cancer 2003;97:934-959.

Moertel CG, Sauer WG, Dockerty MB, \& Baggenstoss AH. (1961). Life history of the carcinoid tumor of the small intestine. Cancer 1961;14:901-912.

Moertel CG, Dockerty MB, \& Judd ES. (1968). Carcinoid tumors of the vermiform appendix. Cancer 1968;21:270-278. 
Moertel CG, Weiland LH, Nagorney DM, \& Dockerty MB. (1987). Carcinoid tumor of the appendix: treatment and prognosis. N Engl J Med 1987;317:1699-1701.

Moertel CG, Kvols LK, \& O'Connell MJ, et al., (1991). Treatment of neuroendocrine carcinomas with combined etoposide and cisplatin. Evidence of major therapeutic activity in the anaplastic variants of these neoplasms. Cancer 1991;68:227-232.

Moses RE, Frank BB, Leavitt M, \& Miller R. (1986).The syndrome of type A chronic atrophic gastritis, pernicious anemia, and multiple gastric carcinoids. J Clin Gastroenterol 1986;8:61-65.

Nassar AA, Jaroszewski DE, Helmers RA, Colby TV, Patel BM, Mookadam F. (2011) Diffuse idiopathic pulmonary neuroendocrine cell hyperplasia: a systematic overview. Am J Respir Crit Care Med. 2011 Jul 1;184(1):8-16. Epub 2011 Mar 25

Nessi R, Basso Ricci P, Basso Ricci S, Bosco M, Blanc M, \& Uslenghi C. (1991). Bronchial carcinoid tumors: radiologic observations in 49 cases. J Thorac Imaging 1991;6:47-53.

Norheim I, Oberg K, Theodorsson-Norheim E, Lindgren PG, Lundqvist G, Magnusson A, Wide L, \& Wilander E. (1987). Malignant carcinoid tumors. An analysis of 103 patients with regard to tumor localization, hormone production, and survival. Ann Surg 1987;206:115-125.

Oberg K, Norheim I, \& Lind E, et al., (1986). Treatment of malignant carcinoid tumors with human leukocyte interferon: long-term results. Cancer Treat Rep 1986;70:1297-1304.

Oberndorfer S. (1907). Karcinoide Tumoren des Dunndarms. Frankfurt II Pathol 1907;1:14261429.

O'Dorisio TM, Krutzik SR, Woltering EA, Lindholm E, Joseph S, Gandolfi AE, Wang YZ, Boudreaux JP, Vinik AI, Go VL, Howe JR, Halfdanarson T, O'Dorisio MS, Mamikunian G. (2010). Development of a highly sensitive and specific carboxyterminal human pancreastatin assay to monitor neuroendocrine tumor behavior. Pancreas. 2010 Jul;39(5):611-6.

Orlefors H, Sundin A, Ahlstrom H, Bjurling P, Bergstrom M, Lilja A, Langstrom B, Oberg K, \& Eriksson B. (1998). Positron emission tomography with 5-hydroxytryprophan in neuroendocrine tumors. J Clin Oncol 1998;16:2534-2541.

Que FG, Nagorney DM, Batts KP, Linz LJ, \& Kvols LK. (1995). Hepatic resection for metastatic neuroendocrine carcinomas. Am J Surg 1995;169:36-43.

Paties C, Zangrandi A, Vassallo G, Rindi G, Solcia E. (1991). Multidirectional carcinoma of the thymus with neuroendocrine and sarcomatoid components and carcinoid syndrome. Pathol Res Pract. 1991 Mar;187(2-3):170-7.

Raymond E, Dahan L, Raoul JL, Bang YJ, Borbath I, Lombard-Bohas C, Valle J, Metrakos P, Smith D, Vinik A, Chen JS, Hörsch D, Hammel P, Wiedenmann B, Van Cutsem E, Patyna S, Lu DR, Blanckmeister C, Chao R, Ruszniewski P. (2011). Sunitinib malate for the treatment of pancreatic neuroendocrine tumors. N Engl J Med. 2011 Feb 10;364(6):501-13. Erratum in: N Engl J Med. 2011 Mar 17;364(11):1082.

Rindi G, Luinetti O, Cornaggia M, Capella C, \& Solcia E. (1993). Three subtypes of gastric argyrophil carcinoid and the gastric neuroendocrine carcinoma: a clinicopathologic study. Gastroenterology 1993;104:994-1006.

Robiolio PA, Rigolin VH, \& Harrison JK, et al., (1995). Predictors of outcome of tricuspid valve replacement in carcinoid heart disease. Am J Cardiol 1995;75:485-488.

Rosenberg JM, \& Welch JP. (1985). Carcinoid tumors of the colon: a study of 72 patients. Am J Surg 1985;149:775-779. 
Safford SD, Coleman RE, Gockerman JP, Moore J, Feldman J, Onaitis MW, Tyler DS, \& Olson JA Jr. (2004). lodine-131 metaiodobenzylguanidine treatment for metastatic carcinoid. Results in 98 patients. Cancer 2004;101:1987-1993.

Scarpignato C, \& Pelosini I. (2001). Somatostatin analogs for cancer treatment and diagnosis: an overview. Chemotherapy 2001;47(Suppl 2):1-29.

Schott, M; Klöppel, G; Raffel, A; Saleh, A; Knoefel, W T; Scherbaum, WA. (2011). Neuroendocrine Neoplasms of the Gastrointestinal Tract. Dtsch Arztebl Int 2011; 108(18): 305-12

Schupak KD, \& Wallner KE. (1991). The role of radiation therapy in the treatment of locally unresectable or metastatic carcinoid tumors. Int J Radiat Oncol Biol Phys 1991;20:489495.

Shaw PA. (1990). Carcinoid tumours of the appendix are different. J Pathol 1990;612:189-190.

Sjoblom SM, Sipponen P, \& Jarvinen H. (1993). Gastroscopic follow-up of pernicious anaemia patients. Gut 1993;34:28-32.

Smith RA. (1969). Bronchial carcinoid tumours. Thorax 1969;24:43-50.

Strosberg JR, Fine RL, Choi J, Nasir A, Coppola D, Chen DT, Helm J, Kvols L. (2011). Firstline chemotherapy with capecitabine and temozolomide in patients with metastatic pancreatic endocrine carcinomas. Cancer. 2011; Jan 15;117(2):268-75. doi: 10.1002/cncr.25425. Epub 2010 Sep 7.

Sundin A, Eriksson B, Bergstrom M, Langstrom B, Oberg K, \& Orlefors H. (2004). PET in the diagnosis of neuroendocrine tumors. Ann N Y Acad Sci 2004;1014:246-257.

Sutton R, Doran HE, \& Williams EM, et al., (2003). Surgery for midgut carcinoid. Endocr Relat Cancer 2003; 10:469-481.

Thompson GB, van Heerden JA, Martin JK Jr, Schutt AJ, llstrup DM, \& Carney JA. (1985). Carcinoid tumors of the gastrointestinal tract: presentation, management, and prognosis. Surgery. 1985;98:1054-63.

Thorson A, Biorck G, \& Bjorkman G, Waldenstrom J. (1954). Malignant carcinoid of the small intestine with metastases to the liver, valvular disease of the right side of the heart (pulmonary stenosis and tricuspid regurgitation without septal defects), peripheral vasomotor symptoms, bronchoconstriction, and an unusual type of cyanosis; a clinical and pathologic syndrome. Am Heart J 1954;47:795-817.

Taal BG, Hoefnagel CA, \& Valdes Olmos RA, et al., (1996). Palliative effect of metaiodobenzylguanidine in metastatic carcinoid tumors. J Clin Oncol 1996;14:1829-1838.

Vinik A. (January 28, 2008). Carcinoid Tumors, In: Endotext, October 30, 2011, Available from:

http:/ / www.endotext.org/guthormones/guthormone2/guthormoneframe2.htm

Waldherr C, Pless M, Maecke HR, Haldemann A, \& Mueller-Brand J. (2001). The clinical value of [90Y-DOTA]-D-Phe1-Tyr3-octreotide (90Y-DOTATOC) in the treatment of neuroendocrine tumours: a clinical phase II study. Ann Oncol 2001;12:941-945.

Williams ED, \& Sandler M. (1963). The classification of carcinoid tumours. Lancet 1963;1:238239.

Yamashina M \& Flinner RA. (1985). Concurrent occurrence of adenocarcinoma and carcinoid tumour in the stomach: A composite tumour or collision tumors? Am J Clin Pathol 1985;83:233-6. 
Yao JC, Phan A, Hoff PM, Chen NX, Charnsangavej C, Yeung SC, Hess K, Ng C, Abbruzzese JC, \& Ajani JA. (2008) Targeting vascular endothelial growth factor in advanced carcinoid tumor: a random assignment phase II study of depot octreotide with bevacizumab and pegylated interferon alpha-2b. J Clin Oncol. Vol.26, 2008 Mar 10; 26(8):1316-23.

Yao JC, Hassan M, Phan A, Dagohoy C, Leary C, Mares JE, Abdalla EK, Fleming JB, Vauthey JN, Rashid A, Evans DB. (2008). One hundred years after "carcinoid": epidemiology of and prognostic factors for neuroendocrine tumors in 35,825 cases in the United States. J Clin Oncol. 2008 Jun 20;26(18):3063-72

Yao JC, Shah MH, Ito T, Bohas CL, Wolin EM, Van Cutsem E, Hobday TJ, Okusaka T, Capdevila J, de Vries EG, Tomassetti P, Pavel ME, Hoosen S, Haas T, Lincy J, Lebwohl D, Öberg K; RAD001 in Advanced Neuroendocrine Tumors, Third Trial (RADIANT-3) Study Group. (2011). Everolimus for advanced pancreatic neuroendocrine tumors. N Engl J Med. 2011 Feb 10;364(6):514-23.

Yildiz O, Ozguroglu M (2006). Carcinoid tumors, In:Neuroendocrine Tumors of Gastroenteropanceatic System, Suayip Yalcin, Huseyin Abali, pp. (117-135), Form Reklam Hizmetleri, ISBN:975-00787-0-5, Ankara

Yildiz O, Ozguroglu M, Yanmaz T, Turna H, Serdengecti S, Dogusoy G. (2010) Gastroenteropancreatic neuroendocrine tumors: 10-year experience in a single center. Med Oncol. 2010 Dec;27(4):1050-6. Epub 2009 Nov 3.

Zar N, Garmo H, Holmberg L, Rastad J, \& Hellman P. (2004). Long-term Survival of Patients with Small Intestinal Carcinoid Tumors. World J Surg 2004;28:1163-1168. 


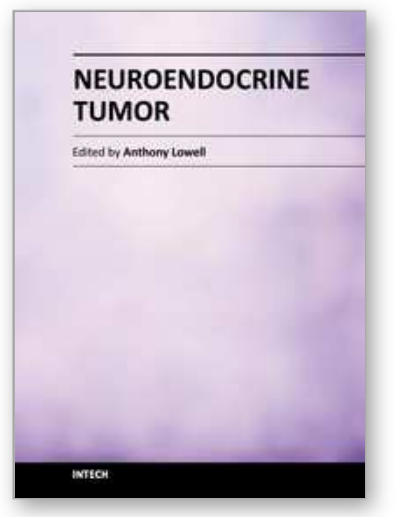

\author{
Neuroendocrine Tumor \\ Edited by Dr. Anthony Lowell
}

ISBN 978-953-51-0653-1

Hard cover, 64 pages

Publisher InTech

Published online 05, June, 2012

Published in print edition June, 2012

\title{
How to reference
}

In order to correctly reference this scholarly work, feel free to copy and paste the following:

Ozcan Yildiz and Suheyla Serdengecti (2012). Gastrointestinal Neuroendocrine Tumors, Neuroendocrine Tumor, Dr. Anthony Lowell (Ed.), ISBN: 978-953-51-0653-1, InTech, Available from: http://www.intechopen.com/books/neuroendocrine-tumor/gastrointestinal-neuroendocrine-tumors

\section{INTECH}

open science | open minds

\section{InTech Europe}

University Campus STeP Ri

Slavka Krautzeka 83/A

51000 Rijeka, Croatia

Phone: +385 (51) 770447

Fax: +385 (51) 686166

www.intechopen.com

\section{InTech China}

Unit 405, Office Block, Hotel Equatorial Shanghai

No.65, Yan An Road (West), Shanghai, 200040, China 中国上海市延安西路65号上海国际贵都大饭店办公楼 405 单元 Phone: +86-21-62489820

Fax: +86-21-62489821 
(C) 2012 The Author(s). Licensee IntechOpen. This is an open access article distributed under the terms of the Creative Commons Attribution 3.0 License, which permits unrestricted use, distribution, and reproduction in any medium, provided the original work is properly cited. 